\section{Scientific Meetings and the Public}

Mr. T. SHEPPARD, director of the Municipal Museums, Hull, contributes to the October issue of the Naturalist some notes on points of interest connected with the recent meeting of the British Association at Aberdeen. In a paragraph on "Lectures and Lecturers" he says, "We have complained over and over again of the apparent inability of many of the lecturers to give audible and understandable discourse" ; and he refers to the plea made at the meeting by Mr. H. T. Tizard, and on many other occasions, for increased care by scientific workers in speech and writing. Unfortunately, some authors of papers seem to be unaware of the most elementary principles of speaking to an audience. If they read their papers, they speak to the desk with their heads down, and if they use blackboards or diagrams they turn their backs to the assembly. While research is being carried on into the conditions of good acoustics in buildings, and architects are criticised for not taking these conditions into consideration, many scientific men would apparently not trouble to make themselves heard in the most perfectly designed building; and even when a microphone is provided they turn away from it. In a communication to a scientific society, inability to speak with ease is perhaps pardonable when an investigator is presenting the results of original research to other workers in the same field. The British Association, however, "seeks to promote general interest in science and its applications". No technical qualification is required for membership, and every year the public is invited to join and attend the meeting. There are thus particular reasons why speakers in the section rooms or elsewhere should remember the character of the assembly they are addressing. Whatever the nature of the audience, however, if an author is not prepared to take the trouble to make himself audible and intelligible, he should not be permitted to irritate his hearers and his paper should be 'taken as read'.

\section{Science and Social Reconstruction}

Is the eighth Steinmetz Memorial Lecture delivered before the Schenectady Section of the American Institute of Electrical Engineers on January 10, Dr. C. E. Kenneth Mees, under the title "Scientific Thought and Social Reconstruction", endeavoured to assess the contribution which men of science can make to the solution of our social and economic problems. While the lag between a scientific discovery and its application tends to decrease and consequently the rate of change produced by scientific knowledge to increase, he does not think that the rate of change will continue to increase. It is highly probable that our social system is in an unstable phase, but after a period of rapid change in which the state of strain is relieved, it should settle into a new and stable phase. While admitting that the man of science must be actively concerned with the vast social and political experiments of our time, Dr. Mees does not consider it would be wise for him to take up the burdens of the politician. He believes that the chief contribution of science to social recon- struction is the method and spirit in which the scientific worker approaches his own work of creating ordered knowledge which is then available for all.

THe transformation of technical industry in the last twenty years is due as much to the growth of the scientific spirit in all sections of the industrial organisation as to the actual laboratory work, and a like transformation in government is required. The use of the scientific spirit in Government would be effectively promoted by scientific men expounding insistently the nature of scientific thought and studying its application to our social and political problems. Discussing the part played by emotion in politics and the opposition between science and arbitrary authority, Dr. Mees insisted on the necessity for some appreciation on the part of men of science of the impossibility of leaders of a democracy being entirely scientific in their attitude. The transformation of industry already indicates the possibility of orderly evolution, and problems of social reconstruction could ultimately be dealt with in the same way as other problems, if men of science set themselves continuously to assist in the wise selection of leaders and in the education of the community as to the meaning of the scientific method and spirit.

\section{Vocational Guidance and Juvenile Employment}

The National Advisory Councils for Juvenile Employment have issued a joint report on the organisation and development of the vocational guidance services in Great Britain (H.M. Stationery Office). The report gives the history of the national scheme for advising boys and girls on the choice of employment. The first attempt on a national basis dates from the Labour Exchanges Act of 1910, when special provision was made for young applicants. It is estimated that probably one in every four of the total number of engagements of juvenile staff is effected through the official organisations of the local committees for juvenile employment. The methods by which advice is given on industrial and kindred matters fall into two divisions-collective and individual. The former includes lectures, visits to factories, display of films and slides on industrial subjects. Individual advice is given to more than a quarter of a million boys and girls, so that roughly rather more than one in three receive expert advice before entering upon initial employment.

THE basis of all sound vocational advice is the alliance of the teachers' knowledge of the individual juvenile's educational and personal capacity with the industrial knowledge of the juvenile committees. The hope is expressed that there should be a reconsideration of the form of the schoolleaving report so as to make it more adequate. Finally, in this connexion there is a survey of the experimental work in industrial psychology as an aid to vocational guidance. The principal published experiments are given in an appendix, and consideration of the claims made leads the authors of the report to the conclusion that "the application of psychological methods to 
vocational guidance should still be regarded as at the experimental stage" though "sufficiently encouraging to justify the continuance of experiments". It is therefore recommended that the Industrial Health Research Board in co-operation with the Ministry of Labour should carry out further experiment. Various suggestions are made for the coordinating of existent services and for a better interchange of information between the various bodies concerned.

\section{Present and Past World Problems}

Dr. Nicholas Murray Butler has been protesting, in an address delivered at Columbia University's summer session convocation on August 7, against the absurdity of treating the world problems of our time as if they were unprecedented-as if there had been no tests in the past of theories and ideals of social, economic and political life as applied to conditions fundamentally similar. Between 1776 and 1789, the thirteen American States faced every single problem which the nations of the world face to-day. What those sovereign States were doing then, indulging in internecine tariff wars, boycotts, export prohibitions, pandering to short-sighted prejudices and particularist passion, the sovereign nations of the world are doing now. The substantial identity of the problems and of the futile tactics with which it was sought to circumvent them are illustrated by passages quoted from the works of F. S. Oliver and John Fiske and from State papers. It was Alexander Hamilton who, combining an acute intelligence, assiduous study, varied experience, indomitable courage, tenacity of purpose, persuasive eloquence and whole-hearted devotion to ideals, saved the States from the ruin towards which they were drifting, and it is by the application of the spirit of his policies to the needs of the nations of the world to-day that these may yet be saved from the world chaos with which we are threatened. The title of the address is "The World needs another Alexander Hamilton".

\section{Work of the Meteorological Office}

THE annual report of the Director of the Meteorological Office for the year ended March 31, 1934 (London: H.M. Stationery Office. 1s. net) is on the same general lines as previous reports, but is somewhat longer, numbering sixty pages; this expansion has its counterpart in an all-round increase in the activities of most of the different sections of the Office, in particular as regards the number of persons or institutions that were supplied with meteorological information, particulars of which are given in the report. In one respect, however, this report differs from those of recent years; it is made more self-contained by a modification of the introductory matter into a fairly detailed exposition of the normal work of the Meteorological Office, especially that part of it connected with synoptic meteorology which involves the collection of data broadcast by foreign countries and by ships at sea, and the supply of such data for the British Isles and neighbouring seas in return; little or no know. ledge of such matters is assumed on the part of the reader. The statisties relating to the work performed in response to external demands for information show in some cases a striking rate of increase ; for example, the forecast service dealt with 10,166 inquiries for the Press compared with 8,705 in the previous year, an advance that cannot wholly be explained by the abnormal weather of 1933-34, although this was doubtless partly responsible for it. In the section concerned with British climatology, where inquiries about past weather, some of which are of a very detailed character, are dealt with, the number of such inquiries was 2,222, and it is stated that in comparison with the annual figure ten years back, this represents a six-fold increase. The report not only summarises the activities of the branches of the Office at headquarters, located in Kingsway, London, and at Exhibition Road, South Kensington, but also those of the observatories and of the branches in Scotland, Malta, Egypt and Iraq.

\section{Co-operation between Aeronautics and Meteorology}

AN interesting case of co-operation between scientific workers to their mutual advantage is revealed in the annual report of the Meteorological Office. The Royal Air Force has established a meteorological flight at Duxford Aerodrome, Cambridge, which consists of two aeroplanes with the necessary pilots and ground staff. Their particular duty is to collect information regarding the upper air, and flights are made daily to heights of $25,000-30,000$ feet. These flights often involve penetrating cloud layers several thousands of feet thick, and such is the keenness of the station personnel that more than 90 per cent of the scheduled flights have been completed during the past year. Information developed. from this is prepared specially for civil flying and distributed from such centres as Croydon. The report states "The rapid growth of flying in and above clouds on the Continental air routes, and the practice of following a direct compass course between the terminal aerodromes, have necessitated the forecasting of much more critical conditions than formerly. Consequently the work at Croydon has become highly specialised and necessitates forecasters of considerable experience of the peculiarities of these air routes, which - in the opinion of pilots of wide experienceare the most difficult from a meteorological point of view of any in the world". 336 gale warnings were issued during the year, of which 81 per cent were justified. It has also been established that there is a fair measure of agreement between the frequency of thunderstorms and the occurrence of sunspots in high northern and tropical latitudes, though not so marked in the temperate zones.

\section{Biological Field Station near Sydney}

ThE Sydney University Biological Society has recently opened a field research station at Narrabeen, the erection and fitting of which was accomplished at a very modest cost by members of the Society and of the Sydney University Rover Scouts ; the building

(Continued on page 623.) 